\title{
Quasi Governments and Inchoate Law: Berle's Vision of Limits on Corporate Power
}

\author{
Elizabeth Pollman*
}

\section{INTRODUCTION}

This Berle X Symposium essay gives prominence to distinguished corporate law scholar Adolf A. Berle, Jr. and his key writings of the 1950s and 1960s. Berle is most famous for his work decades earlier, in the 1930s, with Gardiner Means on the topic of the separation of ownership and control, ${ }^{1}$ and for his great debate of corporate social responsibility with E. Merrick Dodd. ${ }^{2}$ Yet the world was inching closer to our contemporary one in terms of both business and technology in Berle's later years and his work from this period deserves attention.

For corporate law scholars who set their sights facing ahead rather than behind, this mid-twentieth century period of business law literature may appear as a blank space in the annals of scholarly inquiry into corporations. Perhaps the best-known description of this time comes from Yale law professor Bayless Manning who wrote in 1962 that "corporation law, as a field of intellectual effort, is dead in the United States.", According to Manning:

\footnotetext{
* Professor of Law, Loyola Law School, Los Angeles. Many thanks to Charles O'Kelley, the Adolf A. Berle, Jr. Center on Corporations, Law \& Society, Seattle University School of Law, and symposium participants.

1. See generally Adolf A. Berle \& Gardiner C. Means, The Modern Corporation \& PRIVATE PROPERTY (1932).

2. Compare A. A. Berle, Jr., Corporate Powers as Powers in Trust, 44 HARV. L. Rev. 1049 (1931), with E. Merrick Dodd, Jr., For Whom are Corporate Managers Trustees?, 45 HARV. L. REV. 1145 (1932), and A. A. Berle, Jr., For Whom Corporate Managers are Trustees: A Note, 45 HARV. L. REV. 1365 (1932). For discussion of the Berle-Dodd debate, see William W. Bratton \& Michael L. Wachter, Shareholder Primacy's Corporatist Origins: Adolf Berle and The Modern Corporation, 34 J. CORP. L. 99, 122-35 (2008); Charles R. T. O'Kelley, Merrick Dodd and the Great Depression: A Few Historical Corrections, 42 SeAtTLE U. L. REV. 513 (2019).

3. Bayless Manning, The Shareholder's Appraisal Remedy: An Essay for Frank Coker, 72 YALE L.J. 223, 245 n.37 (1962).
} 
When American law ceased to take the 'corporation' seriously, the entire body of law that had been built upon that intellectual construct slowly perforated and rotted away. We have nothing left but our great empty corporation statutes - towering skyscrapers of rusted girders, internally welded together and containing nothing but wind. ${ }^{4}$

Although traditional corporate law may have quieted to an empty city blown by winds, Berle's work during this mid-twentieth century period reflects a lively intellectual effort to describe and predict a new path of laws affecting business corporations. By the early 1950s, Berle had rejoined academic life after years in government service, including a stint as U.S. Ambassador to Brazil. ${ }^{5}$ When he returned to scholarly writing, Berle resumed exploring the concentration of power that corporations represented in U.S. society, and did so in the post-Depression era with particular sensitivity to the potential for expanding legal liabilities and responsibilities. ${ }^{6}$

In a series of publications, Berle repeatedly highlighted the problem of economic power in corporations. He wrote about the issue as one of "bigness" as an absolute matter and as relative to particular industries in terms of concentration. ${ }^{7}$ In a 1958 article, he noted: "Practically all of American industry is now held in corporate form. Probably two-thirds of it is held or operated by not more than 600 large corporations." 8 Following

4. Id.; see also JAMES WILLARD HURST, THE LEGITIMACY OF THE BUSINESS CORPORATION IN THE LAW OF THE UNITED STATES 1780-1970, at 10, 155 (1970) (discussing Manning's perspective and noting that "Manning struck his appraisal in the 1960's, after a generation's stable acceptance of the enabling-act type of corporation law, which emerged as a national norm out of developments at the turn of the century"); Harwell Wells, "Corporation Law is Dead": Heroic Managerialism, Legal Change, and the Puzzle of Corporation Law at the Height of the American Century, 15 U. PA. J. BuS. L. 305, 305 (2013) (explaining "the distinctive features of corporate law in the 'long 1950s,' why the field appeared vibrant at the time, and how later changes in the American political economy led most to eventually agree with Manning's diagnosis").

5. Robert B. Thompson, Adolf Berle During the New Deal: The Braintruster as an Intellectual Jobber, 42 SEATTLE U. L. REV. 663 (2019).

6. See, e.g., Adolf A. Berle, Jr., Modern Functions of the Corporate System, 62 COLUM. L. REV. 433, 433 (1962) [hereinafter Berle, Modern Functions] (discussing how later generations discussed his work as "folklore" but he had lived through the early twentieth century, "a corporate and financial world without the safeguards of the Securities and Exchange Commission, without systemization and forced publicity of corporate accounting, without (more or less) consistent application of antitrust laws, without discouragement of financial pyramiding").

7. Adolf A. Berle, Jr., Legal Problems of Economic Power, 60 ColuM. L. ReV. 4 , 4 (1960) [hereinafter Berle, Economic Power]. For a contrasting view of bigness as unavoidable, with the "real problem" as making sure that "it be possible for small enterprises to exist side by side with the giants," see Peter F. Drucker, The New Society: The Anatomy of Industrial Order 342-44 (Transaction Publishers 1993) (1950).

8. Adolf A. Berle, Jr., "Control” in Corporate Law, 58 ColuM. L. Rev. 1212, 1212 (1958) [hereinafter Berle, Control]; see also Berle, Modern Functions, supra note 6, at 434 ("Within the industrial sphere the degree of concentration has remained about the same. But the aggregate of 
this assertion, he conceded, "history seems to have vindicated" the late Professor E. Merrick Dodd that 'directors, or 'management,' of any of these corporations are no longer merely stewards ... for their stockholders." Large corporations had "outgrown the "incorporated partnership' phase" of business history and Berle concluded that the directors of these large corporations "are also stewards for the employed personnel, for customers and suppliers, and indeed for that section of the community affected by their operations." 10 The community had grown to expect that goods and services would be supplied at an "acceptable" price, that employment opportunities would be provided, and that industries would keep pace with technological progress. ${ }^{11}$ In Berle's eyes, "the huge modern corporation fit[] awkwardly" with free market economic theory. ${ }^{12}$

At the forefront of his 1950s and 1960s writings were two additional concepts describing mechanisms by which the law could control corporations and reign in their encroachments on individual liberty. The first was the notion of corporations as quasi governments, subject to the application of constitutional principles as state actors. ${ }^{13}$ The second was the idea of "inchoate law," a term coined in a seminar at Columbia Law School to describe how the community "moves into action, either through the courts or through the legislature, or through some other form of political intervention" when corporations do not fulfill their expected social roles. ${ }^{14}$

Both concepts are worthy of excavation. From a twenty-first century perspective, the first concept, of corporations as quasi governments, represents a path largely untaken, a prophecy unfulfilled as of yet. It puts into sharp relief the vast expansion of corporate rights rather than responsibilities that developed since the 1970s, and it offers a potential logic, albeit a problematic one, for subjecting corporations to additional limits or preventing the further expansion of corporate rights.

industry, both in size and in relative importance, has established undoubted dominance. Concentration within it is thus markedly more powerful relative to total production and in the total economic sense today than it was in 1932.").

9. Berle, Control, supra note 8, at 1212.

10. Id. As a corollary, Berle suggested that the holders of corporate control had certain responsibilities as well. Id. at 1215 ("[Control] is essentially a variety of political process - non-statist and therefore, in our vocabulary, 'private,' but with substantial public responsibilities. The holder of control is not so much the owner of a proprietary right as the occupier of a power-position.").

11. Berle, Economic Power, supra note 7, at 7.

12. Berle, Modern Functions, supra note 6, at 436.

13. Adolf A. Berle, Jr., Constitutional Limitations on Corporate Activity-Protection of Personal Rights from Invasion Through Economic Power, 100 U. PA. L. REV. 933, 948-53 (1952) [hereinafter Berle, Constitutional Limitations].

14. Berle, Economic Power, supra note 7, at 7-8. 
The second concept, of corporations subject to "inchoate law" that waits ready to spring into action when corporations fail to self-regulate their impacts on citizens, represents a largely forgotten predecessor of subsequent writings by other business law scholars on corporate law federalism, ${ }^{15}$ "bubble laws,"16 "quack corporate governance," 17 and "publicness." "Berle's concept of inchoate law might be fruitfully connected to this significant scholarly work. Further, the concept of inchoate law provides a lens for understanding calls from the business community to embrace social responsibility that have followed in recent decades.

This essay proceeds by engaging each concept in turn and showing its relevance for contemporary issues. First, I observe that Berle's prediction about corporations as quasi governments, subject to constitutional constraints, has largely failed to materialize. The immense power wielded by twenty-first century media and technology giants, such

15. See, e.g., John Armour, Bernard Black \& Brian Cheffins, Delaware's Balancing Act, 87 IND. L.J. 1345 (2012); Stephen M. Bainbridge, The Creeping Federalization of Corporate Law, REG., Spring 2003, at 26; Lucian A. Bebchuk \& Assaf Hamdani, Federal Corporate Law: Lessons from History, 106 Colum. L. Rev. 1793 (2006); William W. Bratton \& Joseph A. McCahery, The Equilibrium Content of Corporate Federalism, 41 WAKE FoREST L. REV. 619 (2006); Mark J. Roe, Delaware's Politics, 118 Harv. L. Rev. 2491 (2005); Renee M. Jones, Does Federalism Matter? Its Perplexing Role in the Corporate Governance Debate, 41 WAKE FOREST L. REV. 879 (2006); Renee M. Jones, Dynamic Federalism: Competition, Cooperation, and Securities Enforcement, 11 ConN. INS. L.J. 107 (2005); Renee M. Jones, Rethinking Corporate Federalism in the Era of Corporate Reform, 29 J. CORP. L. 625 (2004).

16. See, e.g., Stuart Banner, What Causes New Securities Regulation? 300 Years of Evidence, 75 WASH. U. L.Q. 849 (1997); Christopher M. Bruner, Corporate Governance Reform in a Time of Crisis, 36 J. CORP. L. 309 (2011); John C. Coffee, Jr. \& Hillary A. Sale, Redesigning the SEC: Does The Treasury Have a Better Idea?, 95 VA. L. REv. 707 (2009); John C. Coffee, Jr., The Political Economy of Dodd-Frank: Why Financial Reform Tends to Be Frustrated and Systemic Risk Perpetuated, 97 CoRnell L. Rev. 1019 (2012); Erik F. Gerding, The Next Epidemic: Bubbles and the Growth and Decay of Securities Regulation, 38 CONN. L. REV. 393 (2006); A.C. Pritchard, The SEC at 70: Time for Retirement?, 80 Notre DAME L. REV. 1073 (2005); Larry E. Ribstein, Bubble Laws, 40 Hous. L. REV. 77 (2003); Larry E. Ribstein, Market vs. Regulatory Responses to Corporate Fraud: A Critique of the Sarbanes-Oxley Act of 2002, 28 J. CORP. L. 1 (2002); Charles K. Whitehead, Reframing Financial Regulation, 90 B.U. L. REV. 1 (2010).

17. See, e.g., Stephen M. Bainbridge, Dodd-Frank: Quack Federal Corporate Governance Round II, 95 MinN. L. REV. 1779 (2011); Roberta Romano, The Sarbanes-Oxley Act and the Making of Quack Corporate Governance, 114 YALE L.J. 1521 (2005).

18. See, e.g., Donald C. Langevoort \& Robert B. Thompson, "Publicness" in Contemporary Securities Regulation After the JOBS Act, 101 Geo. L.J. 337 (2013); Hillary A. Sale, J.P. Morgan: An Anatomy of Corporate Publicness, 79 BROOK. L. REV. 1629 (2014); Hillary A. Sale \& Robert B. Thompson, Market Intermediation, Publicness, and Securities Class Actions, 93 WASH. U. L. REV. 487 (2015); Hillary A. Sale, Public Governance, 81 GeO. WASH. L. REV. 1012 (2013); Hillary A. Sale, The New "Public" Corporation, LAW \& CONTEMP. ProBS., Winter 2011, at 137; Cary Martin Shelby, Are Hedge Funds Still Private? Exploring Publicness in the Face of Incoherency, 69 SMU L. REV. 405 (2016). 
as Facebook and Twitter, has raised the issue anew but with challenges and complexities to applying the First Amendment that even Berle might find troubling. The concept of corporations as quasi governments is perhaps better regarded as a counterpoint to advocacy for greater expansions of corporate rights, reminding modern thinkers that it is possible to regard corporations not only as private right bearers but also as public actors. Second, I uncover insights from Berle's writings on inchoate law and connect them to current literature, showing that they offer a historical foundation for recent calls for corporations to embrace a more capacious view of their responsibilities.

\section{CORPORATIONS AS QUASI GOVERNMENTS}

Berle engaged in the dangerous practice of making predictions. He vigorously defended this practice without apology, noting he believed that as lawyers and legal scholars "we would be very remiss if we did not" predict the direction of the law and he accepted that some of his predictions might prove to be wrong. ${ }^{19}$

In some respects, ranging from his musings on the pervasive cultural "impact of a new gadget called "TV" ${ }^{20}$ to his intuition that American law was on a path toward responding to "the problem of discrimination on the ground of race or religion," ${ }^{21}$ Berle seems prescient in hindsight or at least an astute observer of cultural shifts at the time.

Yet, the law has also developed quite contrary to his predictions. Chief among those that have proven wrong is his prediction that courts would impose constitutional limits on corporations and their activities. In the years following Berle's prediction, corporations have instead used court battles to vastly expand their own rights.

This Part examines Berle's writings on quasi governments in light of subsequent legal developments and evaluates their potential utility in current debates.

19. Berle, Economic Power, supra note 7, at 22 ("If we do not [predict what the law will be], I myself think we ought to go out of business and I ought to try to get a job at - well, maybe, the RAND Corporation in California, where I can shove things into a machine and go to sleep happily while an IBM pulls out the answer at the end. In other words, I wouldn't need to be a lawyer. I am prepared to defend that against all comers.").

20. Adolf A. Berle, Corporate Decision-Making and Social Control, 24 Bus. LAW. 149, 156 (1968) [hereinafter Berle, Corporate Decision-Making].

21. Adolf A. Berle, Jr., The Developing Law of Corporate Concentration, 19 U. CHI. L. REV. 639, 659 (1952) [hereinafter Berle, Corporate Concentration]. 


\section{A. Berle's Prediction of Constitutional Limits on Corporate Action}

Inspired by cases that were relatively recent at the time, Berle predicted a different world than the one we inherited. Berle saw the beginning of a possible trend in Shelley v. Kraemer, ${ }^{22}$ and Marsh v. Alabama ${ }^{23}$ in which the U.S. Supreme Court refused to enforce racially discriminatory covenants on property transfer and applied constitutional principles to a company town owned and operated by a corporation. As a matter of longstanding principle, for the Constitution to apply there must be state action. ${ }^{24}$ Rarely does a private actor rise to that level - but where others saw limits, Berle saw possibility.

Starting from historical precedent, Berle observed that in early English law corporations were "in form, in fact, and in legal cognizance a device by which the political state got something done." 25 In the seventeenth and eighteenth centuries, in England and in the U.S., corporations resembled "public authorities": "A ferry had to be run; a harbor needed wharves; a colony needed to be developed; a particular line of industry needed encouragement." 26

During this period, corporations were regarded as "an agency of the state," including "when, in 1787, the United States drafted its Constitution." ${ }^{27}$ Berle pointed to Madison's notes from the Constitutional Convention, suggesting that the delegates did not support giving the federal government power to charter corporations because they were "commonly regarded as state monopolies" and "a powerful agency by which the nascent Federal Government might enter, affect, perhaps even control and dominate the commercial field." 28 Later, in McCulloch $v$. Maryland ${ }^{29}$ the Supreme Court held that Congress has power to charter corporations, Berle observed, "but always with the underlying limitation

22. Shelley v. Kraemer, 334 U.S. 1, 20 (1948) (holding that the Fourteenth Amendment prohibits state courts from enforcing racially discriminatory covenants prohibiting transfer of real property); Berle, Constitutional Limitations, supra note 13, at 949-50.

23. Marsh v. Alabama, 326 U.S. 501, 507 (1946) ("Whether a corporation or a municipality owns or possesses the town the public in either case has an identical interest in the functioning of the community in such manner that the channels of communication remain free."); Berle, Constitutional Limitations, supra note 13, at 953.

24. The Civil Rights Cases, 109 U.S. 3, 11 (1883). For discussions of the state action doctrine, see Larry Alexander \& Paul Horton, Whom Does the Constitution Command? A CONCEPTUAl ANALYSis With PRACTICAl IMPLiCATIONS (1988); G. Sidney Buchanan, A Conceptual History of the State Action Doctrine: The Search for Governmental Responsibility, 34 Hous. L. REV. 333 (1997); Erwin Chemerinsky, Rethinking State Action, 80 Nw. U. L. ReV. 503 (1985).

25. Berle, Constitutional Limitations, supra note 13, at 944.

26. Id.

27. Id.

28. Id.

29. McCulloch v. Maryland, 17 U.S. (4 Wheat.) 316 (1819). 
that a federal charter may be granted as a means of performing some function or exercising some power delegated to the United States." ${ }^{30}$

State-chartered corporations likewise "were agencies of the chartering state," and understood as such, according to Berle, until the latter part of the nineteenth century by which time states had adopted general corporation laws. ${ }^{31}$ The "underlying premise" still remained that chartering corporations was "a state act designed to further a state purpose, namely the encouragement of trade and commerce," but corporations were also by then "regarded as a private institution." 32 The corporate form "had virtually become a mere method of business organization" and " $t]$ he operations of the small shop, or of the small factory, did not attain a powerposition capable of invading personality save in rare instances, and these were chiefly in the field of railroads and public utilities." 33

Courts dealt with the concentrated power of railroads as a matter of classic public utility regulation or as regulation of interstate commerce under the commerce clause, including in cases involving racial discrimination. ${ }^{34}$ In 1903, Congress amended the Interstate Commerce Act to make it unlawful for any carrier to subject any person to undue or unreasonable prejudice or disadvantage. ${ }^{35}$ Although Congress may have aimed at issues concerning rebates and preferential rates and services, the Supreme Court, in Mitchell v. United States, held the Interstate Commerce Act gave all travelers the right to equal treatment, but did not address the question of segregation. ${ }^{36}$ At the time of Berle's writing in 1952, he noted that "legal controversy as to what is 'equal treatment' required to be afforded individuals by common carrier regulations is still going on." 37

Berle saw in this legal development the seed of a larger change; in his words, "a quiet translation of constitutional law from the field of political to the field of economic rights." ${ }^{38} \mathrm{He}$ observed that an effect of Mitchell v. United States was to subject corporate policies and practices to legal limits, allowing such policies and practices so long as they were

\footnotetext{
30. Berle, Constitutional Limitations, supra note 13, at 945.

31. Id. at 946.

32. Id.; see also Adolf A. Berle, Jr., The Theory of Enterprise Entity, 47 CoLUM. L. ReV. 343, 344 (1947) ("The legal doctrine of corporate personality was built around the idea of a sovereign grant of certain attributes of personality to a definable group, engaged in an enterprise.").

33. Berle, Constitutional Limitations, supra note 13, at 946.

34. Id. at 947 (discussing Hall v. DeCuir, 95 U.S. 485 (1878), and Chiles v. Chesapeake \& Ohio R.R., 218 U.S. 71 (1910)).

35. Id.

36. Id. (discussing Mitchell v. United States, 313 U.S. 80 (1941)).

37. Id. For a discussion of Brown v. Board of Education, 347 U.S. 483 (1954), and its aftermath, see MARTHA MinOW, IN BROWN's WAKE (2010).

38. Berle, Constitutional Limitations, supra note 13, at 942.
} 
"reasonable" and did not "burden interstate commerce."39 And, "[i]n practice, there is little real difference between this criterion of 'reasonableness' and the criterion of 'equal protection of the laws' applied to state action." 40

Furthermore, Berle looked to Marsh v. Alabama involving the direct application of the Bill of Rights and the Fourteenth Amendment to corporate action and practices. ${ }^{41}$ In Marsh, a sheriff's deputy of a company town, paid by the corporation, arrested a Jehovah's Witness for distributing religious literature on its streets as trespass on private property. ${ }^{42}$ The Supreme Court reversed the conviction for trespass, holding that although the company town was owned and operated by a private corporation, it was performing a "public function" and therefore subject to constitutional limitations. ${ }^{43}$ The Court noted that "the corporation can no more deprive people of freedom of press and religion than it can discriminate against commerce." $" 44$

Shelley v. Kraemer provided further evidence to Berle of shifting tides in state action doctrine. ${ }^{45}$ In Shelley, the Court held that the Fourteenth Amendment prohibited a state court from enforcing a racially discriminatory covenant on transferring real property. ${ }^{46}$ The covenant was a private contractual term; enforcement of it invoked state power.

Beyond explaining this line of logic and authority, Berle was stepping into the realm of prediction making. ${ }^{47} \mathrm{He}$ recognized that " $[\mathrm{t}] \mathrm{he}$ case remains open, so far as authority is concerned, where the corporation is able to enforce its rule, or carry out its practice, without calling on the state to assist in its enforcement." 48 The open question had enormous implications, as Berle recognized, because "most corporate practices and

39. Id. at 948 .

40. Id. Berle further observed that the rule did not seem limited to public utilities. Id. ("A rule or practice, for example, imposed by an oil company, a chain of gasoline stations or even chain stores, could conceivably burden interstate commerce quite as much as any regulation of a railroad.").

41. Id.

42. Marsh v. Alabama, 326 U.S. 501, 503-04 (1946).

43. Id. at 506-07.

44. Id. at 507 n. 4 .

45. Berle, Constitutional Limitations, supra note 13, at 949-50.

46. Shelley v. Kraemer, 334 U.S. 1, 20 (1948).

47. Berle, Constitutional Limitations, supra note 13, at 950 ("There is a gap in direct application of constitutional rules to corporate action which the courts have not yet bridged."); see also Berle, Corporate Concentration, supra note 21, at 658 ("Taking the two lines of argument - that flowing from Shelley v. Kraemer and that flowing from Marsh v. Alabama, the conclusion seems reasonably predictable.").

48. Berle, Constitutional Limitations, supra note 13, at 950. 
regulations are directly applied" without invoking state enforcement power. ${ }^{49}$

The key to understanding how the law would develop, in Berle's view, was to recognize that the economic power concentrated in corporations, in combination with their state-granted charters, had public implications and the potential to impinge on individual liberties. First, states chartered corporations. The same residual power kept by states that could "justify the right of a legislature to change or modify stockholders' rights" implied that the state expected that "the corporation will not exercise its power ... in a manner forbidden the state itself." ${ }^{50}$ Second, corporations would not be subject to constitutional tests "merely" because they operated with state-granted charters. ${ }^{51}$ There would be no wrong, according to Berle, without "very considerable concentration of economic power in a given area." $" 52$ That type of concentration meant that individuals had "either no choice or a very limited choice of suppliers of such goods or services." ${ }^{53}$ Once a corporation wielded that level of actual power, its policies and practices were effectively "public" rules. ${ }^{54}$

In sum, Berle predicted that courts would apply constitutional provisions to corporations as limits on their activities when these two preconditions were met: "the undeniable fact that the corporation was created by the state and the existence of sufficient economic power concentrated in this vehicle to invade the constitutional right of an individual to a material degree." ${ }^{55}$ Berle expected the most likely circumstance in which courts would apply constitutional limits would be where a large corporation with concentrated economic power had discriminated against consumers of its goods and services. ${ }^{56}$ He wrote:

\footnotetext{
49. Id.

50. Id. at 952 .

51. Id.

52. Id. at 951.

53. Id. at 952 .

54. Id. at 953; see also Berle, Corporate Concentration, supra note 21, at 643 ("[T] $]$ he great corporation, as monopoly or in a concentrate, has become increasingly an arm of the state, held to certain of the limitations imposed on the state itself by the Bill of Rights requiring the concentrate to respect certain individual rights and to assure a measure of equal protection of the laws within the scope of its power, as well as to fulfill the economic function it has undertaken of production, supply

55. Berle, Constitutional Limitations, supra note 13, at 943. Berle gave credit to other thinkers around this time, such as Professor Arthur Miller who had suggested similar ideas. Berle, Economic Power, supra note 7, at 9 (noting that in PRIVATE GovernMENTS AND THE CONSTITUTION (1959), Arthur Miller had suggested that corporations are "public organisms" and that courts could "apply fundamental limitations of due process of law to the use of any 'governing power"').

56. Berle, Constitutional Limitations, supra note 13, at 954.
} and service."). 
If, for instance, a corporation dealing in goods or services essential to the life of an individual discriminates against a customer on the ground of race or in a matter which invades his Constitutional right of freedom of speech or religion, it would seem that there is a violation of the guarantees of the Fourteenth Amendment. ${ }^{57}$

Perhaps less likely, in his view, would be application of constitutional provisions when a corporation had discriminated in its provision of access to business opportunity. ${ }^{58} \mathrm{He}$ gave as an example that large corporations such as General Motors and Standard Oil were in a position to potentially discriminate in "the whole complicated gamut of operation from distribution back to production." ${ }^{, 59}$ From decisions about sales agreements to the distribution of products necessary for small businesses to render their services, Berle saw in these relationships the potential for discrimination and encroachment on individual liberty. ${ }^{60}$

\section{B. An Era of Statutory Anti-Discrimination Laws}

Berle's mid-twentieth century work implicated a broader question: Should we protect the individual by judicial application of constitutional provisions to corporations or by legislation? Professor Herbert Wechsler, in his 1959 Holmes lecture at Harvard Law School, made a prediction that has hit closer to subsequent legal developments:

Many understandably would like to perceive in the primary and covenant decisions a principle susceptible of broad extension, applying to the other power aggregates in our society limitations of the kind the Constitution has imposed on government. My colleague A. A. Berle, Jr., has, indeed, pointed to the large business corporation, which after all is chartered by the state and wields in many areas more power than the government, as uniquely suitable for choice as the next subject of such application. I doubt that the courts will yield to such temptations; and I do not hesitate to say that I prefer to see the issues faced through legislation, where there is room for drawing lines that courts are not equipped to draw. If this is right the two decisions I have mentioned will remain, as they now are, ad hoc determinations of their narrow problems, yielding no neutral principles for their extension or support. ${ }^{61}$

57. Berle, Corporate Concentration, supra note 21, at 658.

58. Berle, Constitutional Limitations, supra note 13, at 954.

59. Id.

60. Id.

61. Herbert Wechsler, Toward Neutral Principles of Constitutional Law, 73 HARV. L. REV. 1, 31 (1959). 
As Professor Wechsler suggested, instead of expanding Marsh $v$. Alabama and Shelley v. Kraemer, the Supreme Court has narrowed their reach, although not explicitly overruling them. ${ }^{62}$ The Court has heard several dozen "state action" cases, defining the scope of the Constitution's application on a case-by-case basis, establishing several lines of cases with limited breadth and blurry edges about when a private individual or entity is deemed a state actor. ${ }^{63}$ Observers have characterized the case law as a "doctrinal briar patch"; 64 the Court itself has referred to the state action doctrine as "difficult terrain." ${ }^{65}$ Through all of this, the Court has not broadly interpreted large corporations with economic power as state actors subject to constitutional provisions, as Berle predicted. In fact, the Court has never again ruled as it did in Marsh that the Constitution required large corporations as such to respect individual civil liberties. ${ }^{66}$

Near the end of Berle's life, he witnessed the development of antidiscrimination laws that came about through the legislative process. ${ }^{67}$ Most notably, the Civil Rights Act of 1964 provides for the equal enjoyment of any place of public accommodation without discrimination and prohibits discrimination in employment on the basis of race, national origin, religion, or sex. ${ }^{68}$ When a business challenged the constitutionality of the public accommodations provisions of the Act, the Supreme Court

62. See Lugar v. Edmondson Oil Co., 457 U.S. 922, 928, 937, 939 n.21 (1982) (recognizing that "the party charged with the deprivation [of a federal right] must be a person who may fairly be said to be a state actor" and rejecting the notion "that a private party's mere invocation of state legal procedures" satisfies the state-actor requirement (internal quotation marks and citation omitted)); see also King v. King, 174 P.3d 659, 671 (Wash. 2007) (en banc) (recognizing that "the United States Supreme Court has ... pulled back the reach of Shelley, if not overruling it sub silentio, by requiring 'something more' than the reliance on a ... judicial proceeding" (internal quotation marks omitted)). For further discussion of the state action doctrine in the mid-twentieth century, see SOPHIA Z. LEE, The WorkPlace Constitution: From the NeW Deal to the NeW Right 88-92, 143-47, 149-52, 194-97 (2014).

63. John Dorsett Niles et al., Making Sense of State Action, 51 SANTA CLARA L. REV. 885, 88687 (2011).

64. Ronald J. Krotoszynski, Jr., Back to the Briarpatch: An Argument in Favor of Constitutional Meta-Analysis in State Action Determinations, 94 Mich. L. Rev. 302, 302 (1995).

65. Id.; Lebron v. Nat'l R.R. Passenger Corp., 513 U.S. 374, 378 (1995); see also Edmonson v. Leesville Concrete Co., 500 U.S. 614, 632 (1991) (O'Connor, J., dissenting) (“[O]ur cases deciding when private action might be deemed that of the state have not been a model of consistency.").

66. AdAM WinKLER, We THE CORPORATIONS: HOW AMERICAN BUSINESSES WON THEIR CIVIL RIGHTS 271 (2018); see also Hudgens v. NLRB, 424 U.S. 507, 513 (1976) ("It is, of course, a commonplace that the constitutional guarantee of free speech is a guarantee only against abridgment by government, federal or state .... This elementary proposition is little more than a truism. But even truisms are not always unexceptionably true, and an exception to this one was recognized almost 30 years ago in Marsh v. Alabama ....").

67. See Adolf A. Berle, Jr., Property, Production and Revolution, 65 CoLUM. L. REv. 1, 10-11 (1965) [hereinafter Berle, Property, Production and Revolution] (discussing the Civil Rights Act).

68. 42 U.S.C. $\$ 2000 \mathrm{e}$ et seq (2012). 
swiftly rejected the claims of the business and sustained the Act's validity. ${ }^{69}$ Berle pointed out that the "old concept of "public utilities" could have supported the accommodations provision of the Act, but that Congress had instead used the rationale of the Bill of Rights and the Fourteenth Amendment. ${ }^{70} \mathrm{He}$ seemed to view this development as generally affirming his earlier intuitions about the direction of the law. ${ }^{71}$ Moreover, he did not give up on his prediction, noting that " $[\mathrm{t}]$ he passage of the Civil Rights Act does not, of course prevent the application of constitutional limitations along the lines suggested in my article . ..."72

In subsequent years, Congress enacted additional statutes, including: the Age Discrimination in Employment Act of 1967, which prohibits discrimination against employees 40 years and older ${ }^{73}$ Title VIII of the Civil Rights Act of 1968, as amended, commonly referred to as the Fair Housing Act, which prohibits discrimination in the sale, rental, and financing of dwellings, based on race, national origin, religion, sex, familial status, and disability ${ }^{74}$ and the Americans with Disabilities Act of 1990, which prohibits discrimination in employment on the basis of disabilities and requires that employers reasonably accommodate individuals with disabilities who can otherwise perform a job, among other protections. $^{75}$

These statutes create a patchwork of anti-discrimination laws that can apply to corporations as employers, public accommodations, landlords, and more, but do not specifically target corporations or concentrated economic power as such. ${ }^{76}$ The large body of statutory anti-discrimination laws do not fully parallel constitutional restraints on governments, but they

69. Heart of Atlanta Motel, Inc. v. United States, 379 U.S. 241, 261-62 (1964).

70. Berle, Property, Production and Revolution, supra note 67, at 11 n.32.

71. Indeed, in the early 1950 s Berle predicted not only the application of constitutional limitations to corporations but also the development of statutory law. ADOLF A. BERLE, JR., THE 20TH CEnTURy CAPitAlist Revolution 106 (1954) [hereinafter Berle, 20TH CENTURy] ("[T]he long evolution of constitutional law through court decision ... will probably cover the territory in fulness of time. But test cases are difficult and expensive, and while they are being awaited and carried forward, thousands of individuals may suffer bitterly. Some sort of modern civil rights act . . . seems clearly indicated.").

72. Berle, Property, Production and Revolution, supra note 67, at 19 n.47 ("This could, as I think it does, include recognition that collective operations - predominantly conducted by corporations - as they attain size and power, are assimilable to statist operations, and are governed by the same constitutional limitations.").

73. 29 U.S.C. $\S 621$ et seq.

74. 42 U.S.C. $\$ 3601$ et seq.

75. 42 U.S.C. $\$ 12101$ et seq.

76. For an overview of anti-discrimination laws, see ROY L. BROOKS ET AL., THE LAW OF DisCRIMINATION: CASES AND PERSPECTIVES (2011). 
have established a reach that case-by-case determinations in state action doctrine have not achieved. ${ }^{77}$

\section{Corporations as Quasi Governments Redux}

One longstanding obstacle to applying constitutional principles to corporations has been the complicated task of drawing lines between when private entities constitute state actors and when they do not. Notably, Berle's own writings were short on details in this regard. He does not explain when there would be "sufficient economic power" to find that a corporation encroached on an individual's constitutional right to "a material degree," such that the corporation should be deemed a state actor. $^{78}$

Contemporary debates have raised anew the issue of applying constitutional provisions to corporations and have surfaced additional concerns. One of the most salient of these modern debates is about the role and regulation of social media and other major digital platforms and technology corporations, such as Facebook, Twitter, and Google.

The dominance of these companies' products and services and the stretch of their influence is nearly irrefutable. In a remark echoing Berle's writings, Facebook CEO-founder, Mark Zuckerberg, admitted: "In a lot of ways Facebook is more like a government than a traditional company. We have this large community of people, and more than other technology companies we're really setting policies." 79 According to one measure, "[s]ixty-two percent of Americans get their news through social media, and most of it via Facebook; a third of all traffic to media sites flows from Google. ${ }^{" 80}$ Americans not only consume news, but also post vast amounts of their own content online. As of 2018, about a quarter of U.S. adults report that they are Twitter users. ${ }^{81}$ Two-thirds of U.S. adults report that they are Facebook users, with about three-quarters of those users accessing

77. For a discussion of the "gap between the constitutional restraints on governments and the limitations imposed on corporations by statute," see Russell B. Stevenson, Jr., Corporations and Social Responsibility in Search of the Corporate Soul, 42 GEO. WASH. L. REV. 709, 732-33 (1974).

78. Berle, Constitutional Limitations, supra note 13, at 943.

79. DAVID KirkPATRICK, THE FACEBOOK EFFECT: THE INSIDE StORY OF THE COMPANy THAT IS CONNECTING THE WORLD 254 (2010).

80. Franklin Foer, World Without Mind: The Existential Threat of Big Tech 6 (2017).

81. Pew Research Center, Social Media USE IN 2018, at 2 (Mar. 1, 2018), http://assets. pewresearch.org/wp-content/uploads/sites/14/2018/03/01105133/PI_2018.03.01_Social-Media_ FINAL.pdf [https://perma.cc/Q92B-ZEXJ]. 
the site on a daily basis. ${ }^{82}$ Nearly three-quarters of U.S. adults use the video-sharing site YouTube, owned by Google's parent company. ${ }^{83}$

Some courts and scholars have begun to consider whether these companies are providing today's versions of town halls and public squares, and accordingly whether the First Amendment should apply to them. ${ }^{84}$ Issues concerning access to speak and listen through these technologies, and due process in imposing any restrictions to these benefits are at stake. ${ }^{85}$

Other commentators have raised an interesting concern about applying the First Amendment in this context: the corporations are serving a useful social role in content moderation. ${ }^{86}$ If the companies providing online platforms were deemed state actors, the First Amendment would constrict their practices of curating content, enforcing online community norms, removing obscene and violent content, and regulating hate speech, bullying, and terrorism. ${ }^{87}$ In short, to take away the ability of online platforms to moderate content would "likely create an internet nobody wants." ${ }^{\prime 8}$ Furthermore, some commentators and policymakers have

82. Id.

83. Id.

84. See Packingham v. North Carolina, 137 S. Ct. 1730, 1737 (2017) (striking down a state statute banning registered sex offenders from online platforms and describing such social media services as a "modern public square"); Kate Klonick, The New Governors: The People, Rules, and Processes Governing Online Speech, 131 HARV. L. REV. 1598, 1602, 1609-11 (2018) (discussing how "courts have struggled with how to conceptualize online platforms within First Amendment doctrine: as state actors, as broadcasters, or as editors"). For an examination of modern workplaces as "private governments" and a proposal for a "workplace constitution" that would "incorporate basic constitutional rights, akin to a bill of rights against employers," see ELIZABETH ANDERSON, PRIVATE GOVERNMENT: HOW EMPLOYERS RULE OUR LiVES (AND WHY We DON’T TALK ABOUT IT) 41, 68 (2017).

85. See Lincoln Caplan, Should Facebook and Twitter Be Regulated Under the First Amendment?, WIRED (Oct. 11, 2017), https://www.wired.com/story/should-facebook-and-twitter-beregulated-under-the-first-amendment/ [https://perma.cc/5Q2S-NGL9].

86. See, e.g., Klonick, supra note 84, at 1658-59 (arguing that finding online platforms to be state actors subject to the First Amendment would be "a result that is both unlikely and normatively undesirable").

87. See id. at 1659; Farhad Manjoo, Can Washington Stop Big Tech Companies? Don't Bet on It, N.Y. TIMES (Oct. 25, 2017), https://www.nytimes.com/2017/10/25/technology/regulating-techcompanies.html (noting the largest technology companies are "being called upon to police free speech, terrorism and sex trafficking, and to defend nations and individuals against existential digital attack"); Thomas Wheatley, Why Social Media Is Not a Public Forum, WAsh. Post (Aug. 4, 2017), http://www.washingtonpost.com/blogs/all-opinions-are-local/wp/2017/08/04/why-social-media-isnot-a-public-forum [https://perma.cc/XMZ8-U9GP] ("Facebook's own terms of use and Community Standards would violate the First Amendment.”).

88. Klonick, supra note 84, at 1659; see also HEATHER Whitney, KNIGHT First AMENDMENT Inst., Search Engines, Social Media, and the Editorial Analogy 29 (2018) https:// knightcolumbia.org/sites/default/files/content/Heather_Whitney_Search_Engines_Editorial_Analogy .pdf [https://perma.cc/KVW5-7VYN] ("Users expect a level of content moderation that would likely be unachievable by a platform constrained by the First Amendment . . . . If the First Amendment rights 
pushed for these corporations to take an even more active role, taking responsibility for the content they distribute in order to combat the proliferation of "fake news" and propagandistic speech and advertising. ${ }^{89}$

In some regards, this discourse echoes Berle's suggestion that society had shifted from a dyadic model consisting of the state and the individual to a pluralist model mediated by other actors. ${ }^{90}$ But it also highlights the complexity of conceptualizing private companies that provide online infrastructure and sites for public discourse in a digital world. ${ }^{91}$ There are concerns that Berle did not foresee about applying constitutional limitations to corporate actors, even those that wield significant power over individuals. And there is the possibility of reorienting understandings of the First Amendment itself in a world that has seen significant changes in communications technologies. ${ }^{92}$ Berle's ideas of corporations as quasi governments, along with other thinkers of his time, provided the beginning to a story that is not yet finished.

\section{The Expansion of Corporate Rights}

Finally, in closing this examination of Berle's concept of quasi governments and subsequent legal history, one additional development must be noted - the vast expansion of corporate rights that began in the 1970s. Just as Berle's great body of work was reaching its conclusion, a new chapter regarding corporations and the Constitution was beginning. This, too, is a part of the unfinished story. Instead of the Constitution

of users were deployed to overturn content moderation as we know it, I suspect these platforms would witness a mass exodus.").

89. For discussion of congressional hearings and the efforts of technology companies to combat the spread of disinformation, see Whitney, supra note 88, at 2-3; Mike Isaac, Facebook Mounts Effort to Limit Tide of Fake News, N.Y. TIMES (Dec. 15, 2016), https://www.nytimes.com/2016/12/15/ technology/facebook-fake-news.html; Nick Wingfield et al., Google and Facebook Take Aim at Fake News Sites, N.Y. TIMES (Nov. 14, 2016), https://www.nytimes.com/2016/11/15/technology/ google-will-ban-websites-that-host-fake-news-from-using-its-ad-service.html; Transcript of Mark Zuckerberg's Senate Hearing, WASH. POST (Apr. 10, 2018), www.washingtonpost.com/news/theswitch/wp/2018/04/10/transcript-of-mark-zuckerbergs-senate-hearing/?utm_term=.1c6f566062cf.

90. For a discussion of this point in the contemporary First Amendment context, see Jack M. Balkin, Free Speech in the Algorithmic Society: Big Data, Private Governance, and New School Speech Regulation, 51 U.C. DAVIS L. REV. 1149, 1153-54 (2018).

91. See id. at 1194 ("Arguing that infrastructure owners are state actors simply replicates the outmoded assumptions of a pre-digital world.").

92. See generally Tim Wu, Knight First AmEndment Inst., Is THE First AmENDMENT OBSOLETE? (2017) https://knightcolumbia.org/sites/default/files/content/Emerging\%20Threats\% 20Tim\%20Wu\%20Is\%20the\%20First\%20Amendment\%20Obsolete.pdf [https://perma.cc/6247T8N9] (discussing major technological and economic developments that have transformed the conditions of speech, including making speech plentiful and listener attention valuable). 
providing a check on corporate power, as Berle predicted, it became a source of additional freedoms from regulation for corporations.

The Supreme Court had recognized corporations as having rights under the Constitution since the early nineteenth century - the concept was certainly not new at the time of Berle's writings. ${ }^{93}$ Until the twentieth century, however, the Court had maintained a well-established distinction between property rights that corporations could enjoy and liberty rights that they could not. ${ }^{94}$ A Supreme Court decision in the 1930s abandoned this distinction in a case involving newspaper corporations and the freedom of the press ${ }^{95}$ but it was not until the 1970s that corporations began to turn to the First Amendment as a source of political power and as a shield against regulation that protected the interests of workers, consumers, and the environment. ${ }^{96}$

Famously, before he was nominated to serve on the Supreme Court in 1971, Lewis F. Powell, Jr., wrote a memorandum for the Chamber of Commerce titled Attack on American Free Enterprise System, which outlined avenues for business to become more politically engaged to fight the growing regulation of business practices. ${ }^{97}$ Powell identified the courts as an essential part of the strategy: "Under our constitutional system, especially with an activist-minded Supreme Court, the judiciary may be the most important instrument for social, economic and political change." 98 The Powell memorandum was just one effort among many that spurred the business community to push for greater rights and influence. ${ }^{99}$

The 1970s saw the rise of business lobbying, and in a series of landmark decisions the Court laid out the groundwork for corporate commercial speech protection and political spending rights under the First

93. Margaret M. Blair \& Elizabeth Pollman, The Derivative Nature of Corporate Constitutional Rights, 56 WM. \& MARY L. REV. 1673, 1680-89 (2015).

94. Id. at 1695-96, 1724; see also WINKLER, supra note 66, at 234.

95. Grosjean v. Am. Press Co., 297 U.S. 233 (1936).

96. Blair \& Pollman, supra note 93, at 1719 ("With limited exception, the question of whether the First Amendment protects corporate commercial speech and political spending did not arise until the 1970s."); John C. Coates IV, Corporate Speech \& the First Amendment: History, Data, and Implications, 30 CONST. COMMENT. 223, 223-24 (2015) (finding that "corporations have increasingly displaced individuals as direct beneficiaries of the First Amendment rights, they have done so recently, but with growing speed" since the 1970s).

97. Memorandum from Lewis F. Powell, Jr. to Eugene B. Sydnor, Jr., Chairman, Educ. Comm., U.S. Chamber of Commerce (Aug. 23, 1971), http://law2.wlu.edu/deptimages/Powell\%20Archives/ PowellMemorandumPrinted.pdf [https://perma.cc/723A-RL83]; see also BENJAMIN WATERHOUSE, THE LAND OF ENTERPRISE 189-90 (2017); WINKLER, supra note 66, at 280-89.

98. WINKLER, supra note 66, at 289 (quoting the Powell memorandum).

99. See id. at 303 ("Powell's memo triggered a complete overhaul of the Chamber's approach to politics - and, more broadly, ushered in a new era in which business lobbyists would come to dominate lawmaking in Washington."). 
Amendment. ${ }^{100}$ These cases culminated in the controversial 2010 decision Citizens United v. FEC, which recognized First Amendment protection for all corporations to make independent political expenditures. ${ }^{101}$ One scholar's recent historical empirical analysis found that "after the burst of judicial activism under the influence of Justice Powell in the mid-1970s, First Amendment cases in which businesses are the primary beneficiary have increasingly displaced cases in which individuals are the primary beneficiary." $" 102$

Businesses have also increasingly pushed for religious liberty rights in recent years. ${ }^{103}$ Most notably, in a 2014 case, Burwell v. Hobby Lobby Stores, Inc., the Court held that for-profit corporations qualify as "persons" under the Religious Freedom Restoration Act and are eligible to claim religious exemptions from general laws such as the Affordable Care Act, which requires employers to provide certain health care coverage to employees. ${ }^{104}$ Further, in 2018, the Supreme Court heard Masterpiece Cakeshop Ltd. v. Colorado Civil Rights Commission, involving a business owner who refused to provide a wedding cake for a same-sex couple and claimed an exemption from state public accommodations law on free exercise and free speech grounds. ${ }^{105}$ The Court held that the state civil

100. Cent. Hudson Gas \& Elec. Corp. v. Publ. Serv. Comm'n of N.Y., 447 U.S. 557, 571-72 (1980) (holding that a state could not completely ban promotional advertising by an electrical utility); First Nat'l Bank of Bos. v. Bellotti, 435 U.S. 765, 795 (1978) (holding unconstitutional a state law that barred banks and corporations from spending money to influence ballot initiatives); Va. State Bd. of Pharmacy v. Va. Citizens Consumer Council, Inc., 425 U.S. 748, 763-64 (1976) (ruling that commercial speech is within the scope of First Amendment protection). For a history of the rise of business lobbying in the twentieth century, see generally LEE DRUTMAN, THE BUSINESS OF AMERICA Is LOBbying: How CORPORATIONS BECAME POLITICIZED AND POLITICS BECAME MORE CORPORATE (2015).

101. Citizens United v. FEC, 558 U.S. 310, 466 (2010). For a legal and historical critique of Citizens United, see Leo E. Strine, Jr. \& Nicholas Walter, Originalist or Original: The Difficulties of Reconciling Citizens United with Corporate Law History, 91 NotRe DAME L. REV. 877 (2016). See also Charles R. O'Kelley, Jr., The Constitutional Rights of Corporations Revisited: Social and Political Expression and the Corporation After First National Bank v. Bellotti, 67 GEO. L.J. 1347 (1979) (discussing an important precedent to Citizens United).

102. Coates, supra note 96, at 262.

103. See THE RiSE OF CORPORATE RELIGIOUS LiBERTY (Micah Schwartzman et al. eds., 2016); Paul Horwitz, The Hobby Lobby Moment, 128 HARV. L. REv. 154, 180-86 (2014); James D. Nelson, Corporate Disestablishment, 105 VA. L. REV. (forthcoming 2019); see also Ronald J. Colombo, The Naked Private Square, 51 Hous. L. Rev. 1 (2013); Alan J. Meese \& Nathan B. Oman, Hobby Lobby, Corporate Law, and the Theory of the Firm: Why For-Profit Corporations Are RFRA Persons, 127 HARV. L. REV. F. 273 (2014)

104. Burwell v. Hobby Lobby Stores, Inc., 134 S. Ct. 2751, 2768-69 (2014).

105. Masterpiece Cakeshop, Ltd. v. Colo. Civil Rights Comm'n, 138 S. Ct. 1719, 1724-26 (2018). 
rights commission had violated the business owner's free exercise rights by failing to consider his claim in a neutral and respectful way. ${ }^{106}$

Setting these legal developments alongside Berle's prediction of the Constitution serving as a limit on corporate power shows how far he missed the mark in his forecast. Perhaps as judicial dissents can plant a seed for a future majority opinion, Berle's concept of corporations as quasi governments could serve as a counterpoint to conceptions that too easily equate corporations with associations of individuals and rationalize further expansions of corporate rights. ${ }^{107}$ As this story continues, Berle's other concept from the 1950s and 1960s — of inchoate law — proves to be a more enduring force.

\section{CORPORATIONS AS SUBJECTS OF INCHOATE LAW}

During the same era that Berle was exploring the idea of corporations as quasi governments, he was mapping an understanding of the laws affecting corporations. This Part connects his writings on this topic to contemporary scholarship and calls for increased social responsibility.

\section{A. Berle's Inchoate Law and Echoes in the Literature}

Berle asserted that the laws affecting corporations fall into two categories. The first category encompasses "the explicit rules laid down by decision or statute and setting out the existing legal capacities and liabilities." ${ }^{108}$ This category exists without dispute as it encompasses laws that are explicitly established on the books. The second, a "more important and more difficult category," Berle referred to as "inchoate law." 109 In his words, this latter category "relates to the duties of corporations, not set out either in decision or statute, but arising from the impact on social and economic situations foreseeably resulting from a corporate course of action." 110

He envisioned a mechanism of legal pushback that arises to limit the sphere of corporate action or to establish liability when corporations fail to self-regulate within expected social norms of responsibility. According to Berle, "When the impact point is reached, it is predictable that a hitherto undetermined liability or responsibility will suddenly emerge as explicit

106. Id. at 1732 .

107. For a discussion of how the Supreme Court's corporate rights jurisprudence has relied on a rationale that corporations represent associations of people, see Blair \& Pollman, supra note 93.

108. Berle, Corporate Decision-Making, supra note 20, at 149.

109. Id.

110. Id. 
law." "He did not provide a fully fleshed out theory but articulated that new law spurred by the social and economic impact of corporations "might come about through sudden demand for and passage of legislation-or through decisions of administrative authorities breaking new ground-or through court-decision extending judicial action beyond previous limit."112 In latent form, this law is inchoate: a mere potential, but perceivable nonetheless. ${ }^{113}$

Berle provided diverse illustrations. For example, he recounted a "public clamor" that resulted when it came to light just before World War II that the head of one of the large oil corporations may have authorized the sale of petroleum through a neutral country to Nazi Germany. ${ }^{114}$ After significant public outcry, the corporation fired the corporate executive. ${ }^{115}$ Contrasting instances like this one in which the corporation took selfcorrecting action, Berle discussed situations in which corporations that failed to do so became subject to government intervention. ${ }^{116}$ The steel industry incurred a "political intervention on a massive and rather disorderly scale" after World War II when companies underestimated steel needs and dismantled facilities financed by the government, causing steel shortages. ${ }^{117}$ Congress commenced investigations, the Department of Justice sprang into action, and a statistician from the Department of Agriculture provided an independent estimate of the country's steel demand. ${ }^{118}$ In his inaugural address, President Harry Truman stated that the government would step in to produce steel if needed. ${ }^{119}$ These responses elicited a pledge by the steel industry to promptly increase productive capacity, and Congress passed the Voluntary Allocation Act, "an extremely crude system of temporary industrial planning," to work out the allocation of products in short supply under government supervision. ${ }^{120}$

111. Id. For an examination of how regulators can act by threat without making hard law, see Tim Wu, Agency Threats, 60 Duke L.J. 1841 (2011).

112. Berle, Corporate Decision-Making, supra note 20, at 149.

113. BERLE, 20TH CENTURY, supra note 71, at 69 (describing "inchoate" as "there, but not explicit, to be apprehended and worked out as you went along").

114. Id. at 54 .

115. Id. For an examination of the use of shaming by private parties in the corporate context, see David A. Skeel, Jr., Shaming in Corporate Law, 149 U. PA. L. REV. 1811 (2001).

116. Berle, Constitutional Limitations, supra note 13, at 934 ("“T] he evolution of law has been largely unsystematic. It has grown out of a series of major or minor crises, all of which have a common element. In each case the industry concerned failed to meet some widespread demand in some quarter of the community with which it dealt. This generated political action energizing intervention in one form or another by the political state.").

117. Berle, Economic Power, supra note 7, at 8.

118. Id.

119. Id.

120. Id. 
Echoes of Berle's ideas reverberate in the works of modern writers. From scholars who have theorized the development of state corporate law in the shadow of federal action ${ }^{121}$ to those who have examined the laws that get passed after financial scandals and crises, ${ }^{122}$ they have observed a similar push and pull of corporate action and societal reaction. These scholars have traced the dynamic behind a range of legal developments, from the political economy of the Dodd-Frank Wall Street Reform and Consumer Protection Act to the changing nature of corporate governance provisions in securities regulation.

One growing literature with parallels to Berle's concept of inchoate law is that of "publicness." ${ }^{23}$ Professor Hillary Sale has articulated how corporate governance transcends a private law sphere and how the public, government, and media have increasing influence over corporations. ${ }^{124}$ Like Berle, she has highlighted that corporations that operate in a public sphere do so "with changing obligations and an evolving, not a fixed, definition." 125 She uses the term publicness in a way that echoes Berle's inchoate law, as both "a process and an outcome" that stem from corporate failures, and she advances understandings of private ordering as well as regulation. ${ }^{126}$ Similarly, Professors Donald Langevoort and Robert Thompson define publicness generally to refer to "what society demands of powerful institutions, in terms of transparency, accountability, and openness, in order for that power to be legitimate."127 They have argued that "to a greater extent than generally acknowledged, the broader demands of publicness drive the creation of contemporary securities regulation." "28 This growing body of work, as well as various other related literatures, offers rich accounts and understandings of the relationship between corporations and regulatory bodies and the public.

121. See supra note 15.

122. See supra notes $16 \& 17$

123. See supra note 18.

124. Sale, The New "Public" Corporation, supra note 18, at 137-38 ("The failure of officers and directors to govern in a sufficiently public manner has resulted not only in scandals, but also in more public scrutiny of their decisions, powers, and duties.").

125. Id. at 138 .

126. Sale, Public Governance, supra note 18, at 1012 ("[C]orporate failures expose 'private' choices .... They reveal the lawmakers' choices about private ordering and self-regulation. They highlight the spaces not yet legally defined: those that were omitted. They create pressure for more reform and public governance.").

127. Langevoort \& Thompson, supra note 18 , at 340 .

128. Id. at 341. 


\section{B. A Description and A Prescription}

Despite some fuzziness in its contours, Berle's concept of inchoate law was not just descriptive but also prescriptive- he wanted lawyers and professionals who worked for corporations to monitor the horizon for coming shifts in the business environment and law and to self-regulate. He wrote:

It is here suggested that a somewhat similar phenomenon [to a higher law] is slowly looming up in the corporate field through the mists that hide from us the history of the next generation. There is beginning to be apparent a realization of a counter force which checks, and remotely acts on, and in time may modify in certain areas the absolute power of business discretion. In our system it emerges in time as law; and good lawyers watch for it. ${ }^{129}$

Expectations had changed. In Berle's youth, corporate counsel were customarily viewed as "tame lawyers" asked to use their professional judgment to advise on specific legal problems. ${ }^{130}$ But by the late $1960 \mathrm{~s}$, Berle explained that these corporate lawyers had an additional role: "sitting at the right hand of the policy-making officers, they have the opportunity, if not the duty, to advise upon the possible consequences, economic, legal and social, of corporate decision-making."131

Corporate managers also bore social responsibility and were subject to the vagaries of inchoate law: "The result at all events has been that in a range of action, where social, political and human problems are pushed up, corporate managements are frequently the first line point of impact. They deal with these as best they can; failing, they or others invoke political or governmental action."132

Berle's work provides a lens for understanding calls from the business community to embrace social responsibility that have followed in recent years. Although not pervasive, the trend is clear that influential players are willing to take on a more capacious role with an understanding of the consequences at stake. ${ }^{133}$

129. Berle, 20Th CENTURY, supra note 71, at 70; see also id. at 107 ("Pending legislation [to provide due process and protect individuals' civil rights], it is suggested that corporations themselves are not wholly without capacity to act. They, in respect of their own operations, can erect their own Aula Regis, and wisdom would suggest that they do.").

130. Berle, Corporate Decision-Making, supra note 20, at 149.

131. Id.

132. Berle, Modern Functions, supra note 6, at 444.

133. Berle, Corporate Decision-Making, supra note 20, at 150 ("Whereas a generation ago, the law was preoccupied with assuring that managements did not victimize their shareholders, preoccupation today is with the extent of their social and political and economic responsibility for the health of the American economic machine, and for employment and welfare of its citizens."). 
For example, at the start of 2018, the chairperson of BlackRock, the world's largest asset manager, sent an open letter to over 1,000 CEOs, explaining: "Society is demanding that companies, both public and private, serve a social purpose." ${ }^{\text {" }}$ He urged the CEOs to "not only deliver financial performance" but also make "a positive contribution to society" by leading their corporations to benefit all stakeholders, "including shareholders, employees, customers, and the communities in which they operate." 135 The BlackRock chairperson instructed the executives to "understand the societal impact of [their] business as well as the ways that broad, structural trends - from slow wage growth to rising automation to climate change - affect [the] potential for growth."136

Similarly, in 2017, when President Donald Trump was deciding whether to pull the United States out of a major international climate change accord, thirty CEOs signed an open letter championing continued commitment to the agreement. ${ }^{137}$ In addition, more than 360 institutional investors with more than $\$ 19$ trillion in assets under management signed a separate letter in support. ${ }^{138}$ When the U.S. President decided to exit, a group of mayors, governors, university presidents, and more than 100 businesses, including some of the largest U.S. companies such as Apple, Exxon Mobil, and Ford Motor Company, negotiated with the United Nations concerning an independent submission to the climate deal. ${ }^{139}$

Berle recognized that the dynamic of inchoate law is an imperfect one. Social and political forces might be slow to commence or extreme in their result. ${ }^{140}$ As he explained, "Exact justice cannot be expected in these situations: someone gets hurt. Yet on the whole community standards for corporate action gradually do assert themselves, and capable corporations

134. Larry Fink, Larry Fink's Annual Letter to CEOs: A Sense of Purpose, BLACKRock, https:// www.blackrock.com/corporate/investor-relations/larry-fink-ceo-letter [https://perma.cc/5KAX$\mathrm{XYMX]}$.

135. Id.

136. Id.

137. Andrew Winston, U.S. Business Leaders Want to Stay in the Paris Climate Accord, HARV. BUS. REV. (May 31, 2017), https://hbr.org/2017/05/u-s-business-leaders-want-to-stay-in-theparis-climate-accord.

138. Press Release, Ceres, Nearly 400 Global Investors Urge G20 to Stand by Paris Agreement and Drive Its Swift Implementation (July 3, 2017), https://www.ceres.org/news-center/pressreleases/over-200-global-investors-urge-g7-stand-paris-agreement-and-drive-its [https:/perma.cc/ BR7W-YFU8].

139. Hiroko Tabuchi \& Henry Fountain, Bucking Trump, These Cities, States, and Companies Commit to Paris Accord, N.Y. TimeS (June 1, 2017), https://www.nytimes.com/2017/06/01/climate/ american-cities-climate-standards.html; see also Elizabeth Pollman, Social and Asocial Enterprise, in The CAMBridge Handbook of Social EnTERPRise LaW (Benjamin Means \& Joseph W. Yockey eds., 2018) (discussing the increasing social and political engagement of business).

140. BERLE, 20TH CENTURY, supra note 71, at 57. 
reach for them and endeavor to meet them." ${ }^{" 141}$ His insight was in providing not only an observation about the laws affecting corporations but also a proposal for action.

\section{CONCLUSION}

"I have said more than enough to get into trouble," Berle remarked in closing one of his last publications. ${ }^{142}$ Although his later work is less famous than his writings from the 1930s, it is full of the kinds of insights that can provoke, challenge, and indeed perhaps even start a little scholarly trouble.

This essay has aimed to shine light on Berle's work from the 1950s and 1960s, and connect it to contemporary debates. With his concepts of corporations as quasi governments and subjects of inchoate law, Berle explored various ways in which society could constrain and ameliorate the impact of corporate power and ultimately preserve the legitimacy of corporations - essential work for generations to come.

141. Id. at 57-58.

142. Berle, Corporate Decision-Making, supra note 20, at 157. 